\title{
Er kvalitativ og kvantitativ forskning misvisende begreper?
}

\author{
Kvalitativ forskning er i ferd med å bli fullt anerkjent innen medisinsk forskning, men det pågår fortsatt en debatt \\ om forskjellene mellom kvalitativ og kvantitativ forskning. Jeg mener at avstanden mellom de to er mindre enn \\ debatten kan gi inntrykk av og at begrepsparet «kvalitativ» og «kvantitativ» med fordel kan legges bort.
}

Kvalitativ medisinsk forskning har de siste ti årene kommet for fullt inn i den etablerte medisinske vitenskapen. Tradisjonell medisinsk vitenskap har til nå vært sterkt dominert av naturvitenskapelige perspektiver, og inntoget av en mer humanvitenskapelig tilnærming har derfor ikke skjedd uten konflikter. Debatten er ikke like intens som den var for 10-20 år siden, men den blusser opp fra tid til annen $(1-5)$. Som laboratoriemedisiner har jeg stått noe på utsiden av debatten, som for det meste har foregått innenfor kliniske forskningsmiljøer. Dette gir meg et visst skråblikk, men min bakgrunn er åpenbart naturvitenskapelig medisin.

\section{Kvantitativ forskning}

Begrepet «kvantitativ forskning» brukes ofte av kvalitative forskere som betegnelse på motpolen til deres egen tilnærming. Begrepet er semantisk sett nærliggende å bruke når man først har introdusert begrepet «kvalitativ», men jeg mener begrepsbruken er problematisk. For det første er det ofte noe uklart hva man legger i kvantitativ forskning. I medisinsk sammenheng brukes begrepet ofte synonymt med «biomedisinsk», «tradisjonell» eller «naturvitenskapelig» $(1-3)$. Jeg tenderer derfor mot å tolke «kvantitativ medisinsk forskning» dit hen at det skal omfatte all ikkekvalitativ medisinsk forskning, det vil si all naturvitenskapelig medisinsk forskning.

Det er mange naturvitenskapelig orienterte medisinske forskere som føler seg lite hjemme i en slik betegnelse. Matematiske eller statistiske metoder er riktignok helt nødvendige i mange naturvitenskapelige tilnærminger, men jeg mener at denne bruken av begrepet tillegger matematikken for stor betydning. Kirsti Malterud skrev for eksempel dette i en hyppig sitert artikkel i The Lancet i 2001: «Numbers alone can never provide the whole range of evidence needed for clinical work...» (1). Ytterst få innen naturvitenskapelig medisin i dag er uenige i dette. De fleste anerkjenner at ikke-tallfestbare sosiokulturelle og psykologiske aspekter spiller en stor rolle. Kvantitering er kun ett av flere grep som kan benyttes til anskueliggjøring av data og til standardisering innen både naturvitenskapelig og humanistisk forskning. En stor del av den basalbiologiske medisinske forskningen foregår på små materialer med minimal bruk av matematikk eller statistikk, for eksempel mikroskopiske strukturstudier, beskrivende studier av

\section{«Det gjelder å komme bort fra paradigme- tankegangen»}

nyoppdagede organismer og molekylære cellestudier med bruk av markører som kun analyseres visuelt. Charles Darwins forskning som ledet frem til evolusjonsteorien, var også nærmest fri for matematikk og statistikk, og jeg synes det er fristende å bruke begrepet «kvalitativ» også om denne.

Ofte synes det som om den randomiserte kontrollerte studien er siktemålet med begrepet «kvantitativ medisinsk forskning». Det skulle være unødvendig, men jeg føler ofte at jeg må presisere at naturvitenskapelig medisinsk forskning er langt mer enn slike studier. Jeg er helt enig i at fokuset på den randomiserte kontrollerte studien, og $i$ enda større grad metaanalysen, er blitt for sterkt i forbindelse med all oppmerksomheten rundt kunnskapsbasert medisin. Mye informasjon går tapt når man kun fokuserer på store studiepopulasjoner og harde endepunkter. Dette gjelder både basalbiologisk og humanistisk informasjon. Også på dette feltet har kvalitative forskere mer til felles med mange naturvitenskapelig orienterte medisinske forskere enn hva man kan få inntrykk av når man følger debatten.

\section{Ikke forskjellige paradigmer}

Det har vært vanlig å hevde at kvalitativ og tradisjonell medisinsk vitenskap tilhører ulike paradigmer, dvs. tenkesett som er gjensidig ekskluderende. Paradigmebegrepet bidrar sterkt til å skape avstand. Det er mange likhetspunkter mellom kvalitativ og naturvitenskapelig medisinsk forskning, og etter min mening er ikke vitenskapsretningene gjensidig ekskluderende. I dag er det mange som deler dette synet - i det minste i praksis. Det stadig økende antallet såkalte kombinasjonsstudier (mixed methods research) illustrerer dette $(2,6)$. Det gjelder å komme bort fra paradigmetankegangen, og jeg foreslår derfor å legge begrepene «kvalitativ» og «kvantitativ» bort i denne sammenheng. De fører til misforståelser og grov kategorisering av vitenskaper som først og fremst kjennetegnes av stort mangfold. For min egen del føler jeg meg langt mer hjemme i betegnelsene «molekylærbiologisk forsker» eller «mikrobiologisk forsker» enn $\mathrm{i}$ «kvantitativ forsker».

\section{Andreas Christensen \\ a.christensen@ntnu.no}

Andreas Christensen (f. 1969) er spesialist i medisinsk mikrobiologi og overlege ved Avdeling for medisinsk mikrobiologi, St. Olavs hospital. Forfatter har fylt ut ICMJE-skjemaet og oppgir ingen interessekonflikter.

\section{Litteratur}

1. Malterud K. The art and science of clinical knowledge: evidence beyond measures and numbers. Lancet 2001; 358: 397-400.

2. Cohen DJ, Crabtree BF. Evaluative criteria for qualitative research in health care: controversies and recommendations. Ann Fam Med 2008; 6: $331-9$

3. Dahlberg K. The scientific dichotomy and the question of evidence. Int J Qual Stud Health Well-being 2013; 8: 21846

4. Castillo-Page L, Bodilly S, Bunton SA. AM last page. Understanding qualitative and quantitative research paradigms in academic medicine. Acad Med 2012; 87: 386.

5. Paley J, Lilford R. Qualitative methods: an alternative view. BMJ 2011; 342: d424

6. Malterud K. A kombinere metoder. I: Malterud K. Kvalitative metoder i medisinsk forskning: en innføring. Oslo: Universitetsforlaget, 2011: 190-7.

Mottatt 11.2. 2014, første revisjon innsendt 9.4. 2014, godkjent 6.5. 2014. Redaktør: Sigurd Høye.

Publisert først på nett. 